\title{
The Presence of $\boldsymbol{N}$-Terminal Methionine on Nascent Protein of Rat Liver and Rabbit Reticulocytes and its Cleavage during Polypeptide-Chain Elongation
}

\author{
By ANNA KOFFER-GUTMANN* and HENRY R. V. ARNSTEIN \\ Department of Biochemistry, University of London King's College, Strand, London WC2R $2 L S$, U.K.
}

(Received 15 March 1973)

\begin{abstract}
1. The size of nascent globin peptides from which the $N$-terminal methionine residue is cleaved has been investigated by comparing the proportion of $N$-terminal methionine and valine in short and long chains. Nascent chains were labelled in rabbit reticulocyte lysates, fractionated according to length by chromatography on Sephadex G-50, and analysed by the Edman degradation of selected pooled fractions. It was found that different peptide fractions contained either methionine or valine, but not both, as the $N$-terminal residue. Methionine was present at the $N$-terminus of globin chains containing up to approx. 50 amino acids whereas valine was found to be the $N$-terminal amino acid of longer peptides. 2. In similar experiments with nascent proteins of rat liver, labelled either in vivo or in a cell-free system containing microsomal material and cell sap, evidence was obtained for the presence of methionine at the $N$-terminus of nascent chains up to approx. 65 amino acid residues long. Thus protein synthesis in liver appears to be initiated also by methionine, but in this case cleavage takes place somewhat later during peptide elongation than in globin synthesis.
\end{abstract}

Protein synthesis by both prokaryotic and eukaryotic cells requires a specific initiator tRNA for the formation of the first peptide bond. In Escherichia coli and other prokaryotic micro-organisms $N$ formylmethionyl tRNA has been shown to initiate polypeptide synthesis (Lengyel \& Söll, 1969). Formylated methionyl tRNA is present also in mitochondria and chloroplasts (Lucas-Lenard \& Lipmann, 1971), but not in the cytoplasm (Marcker \& Smith, 1969), of various eukaryotic cells. An analogous species of methionine-accepting tRNA, designated tRNA Met $^{\text {Met }}$, has been found in the cytoplasm of several eukaryotes (Smith \& Marcker, 1970) and there is now considerable evidence that this tRNA functions as a specific initiator of protein synthesis by $80 \mathrm{~S}$ ribosomes, although in this case the methionine residue remains unformylated (Lucas-Lenard \& Lipmann, 1971).

In agreement with this mechanism of chain initiation by eukaryotic cells, methionine has been found to be present as the $N$-terminal residue of nascent globin chains (Wilson \& Dintzis, 1970; Jackson \& Hunter, 1970), of trout testis protamine (Wigle \& Dixon, 1970) and of viral polypeptides synthesized by cultured human cells after infection with adenovirus (Caffier et al., 1971).

Methionine is, however, not a commonly occurring $\mathrm{N}$-terminal amino acid in proteins of eukaryotic organisms (Brown, 1971) and a mechanism must therefore exist for its cleavage from the $N$-terminal

* Present address: Department of Biochemistry, University College London, Gower Street, London WC1E 6BT, U.K. position at some stage of protein synthesis. In globin biosynthesis, there is evidence for the removal of the terminal methionine residue soon after the nascent globin peptides become acid-precipitable and Jackson \& Hunter (1970) have estimated the chain length to be 15-20 amino acid residues. Essentially similar results were obtained by Yoshida et al. (1970), who found that nascent globin peptides shorter than 16 residues contained $N$-terminal methionine whereas peptides longer than 30 residues contained $N$-terminal valine. With protamine, which has about $\mathbf{3 0}$ amino acid residues, the $N$-terminal methionine is cleaved off only after chain completion. In a few proteins, methionine is found at the amino terminus of the final polypeptide chain. Thus the $\beta$ chains of ox and sheep haemoglobin have methionine as the $N$-terminal amino acid (Boyer et al., 1967) and the $\alpha$ chain of duck haemoglobin also contains $N$-terminal methionine, which has been shown to originate from the initiating tRNA fet $_{\text {Met }}$ species (Pemberton et al., 1972). The underlying mechanism for the conservation of methionine at the $N$-terminus of certain polypeptide chains is not known.

In the present work, the cleavage point of $N$ terminal methionine in rabbit globin chains has been investigated by labelling nascent peptides in a reticulocyte lysate, fractionating them according to chain length by chromatography on Sephadex, and carrying out end-group determinations on selected fractions by the Edman degradation. It was found that the $N$ terminal methionine residue is removed when the nascent globin has reached a chain length of approx. 
50 amino acid residues. In similar experiments with rat liver proteins, evidence has been obtained that in this case also methionine is the initiator, but cleavage seems to occur somewhat later during peptide elongation than in globin synthesis.

\section{Materials and Methods}

\section{Chemicals}

ATP (disodium salt), GTP (trilithium salt), potassium phosphoenolpyruvate and pyruvate kinase were obtained from Boehringer Mannheim G.m.b.H. (Mannheim, Germany). The sources of the other chemicals were as follows: radioactive amino acids were from The Radiochemical Centre (Amersham, Bucks., U.K.); dansylated amino acids and methylisothiocyanate were from BDH Chemicals Ltd. (Poole, Dorset, U.K.): 2,5-diphenyloxazole and 1,4-bis-(5-phenyloxazol-2-yl)benzene were from Koch-Light Laboratories Ltd. (Colnbrook, Bucks., U.K.); heparin (25000i.u./5ml) was from Evans Medical Ltd. (Speke, Liverpool, U.K.); Nembutal $(60 \mathrm{mg} / \mathrm{ml})$ was from Abbott Laboratories Ltd. (Queensborough, Kent, U.K.); fluothane was from ICI Pharmaceutical Division (Macclesfield, Cheshire, U.K.); Sephadex G-25 (fine grade) and G-50 (fine grade) were from Pharmacia (Uppsala, Sweden).

\section{Buffer solutions}

The buffered saline for washing reticulocytes contained $0.154 \mathrm{M}-\mathrm{NaCl}$ and $0.01 \mathrm{M}$-sodium phosphate (pH7).

The medium for homogenizing rat liver (buffer A) was $0.25 \mathrm{M}$-sucrose- $25 \mathrm{mM}-\mathrm{KCl}-10 \mathrm{mM}$-magnesium acetate-35 mM-Tris- $\mathbf{H C l}$ (pH7.8). Buffer $A^{\prime}$ was identical with buffer A except that the sucrose concentration was $0.15 \mathrm{M}$. Buffer B was $25 \mathrm{mM}-\mathrm{KCl}-$ $5 \mathrm{~mm}$-magnesium acetate-35 mM-Tris- $\mathrm{HCl}$ (pH7.8).

\section{Preparation of labelled nascent protein}

Rabbit reticulocyte system. Rabbits (1.5-3 kg body wt.) were made anaemic by four to six intraperitoneal injections of phenylhydrazine and reticulocytes were obtained as previously described (Arnstein et al., 1964). They were washed three times with buffered saline and lysed by the addition of an equal volume of ice-cold water. Except where otherwise stated all subsequent operations were carried out at $0-4^{\circ} \mathrm{C}$. The lysate was centrifuged at $15000 \mathrm{~g}$ for $15 \mathrm{~min}$ to remove cell debris and any residual cells.

Cell-free protein synthesis was done by the method of Lamfrom \& Knopf (1964) in a mixture consisting of the above-mentioned lysate ( $4 \mathrm{vol}$.) and a solution, 'lysate mix' (1 vol.), containing $5 \mathrm{~mm}$-ATP, $1.25 \mathrm{~mm}$ GTP, $25 \mathrm{~mm}$-phosphoenolpyruvate, pyruvate kinase $(250 \mu \mathrm{g} / \mathrm{ml}), 50 \mathrm{~mm}-\mathrm{Tris}-\mathrm{HCl}$ (pH7.8), 500mM-am- monium acetate, $20 \mathrm{~mm}$-magnesium acetate, $30 \mathrm{~mm}-2$ mercaptoethanol, and each of the 20 protein amino acids $(0.5 \mathrm{~mm})$, except the radioactive precursor, which was added in the amounts given for different experiments. The mixtures were incubated in conical flasks $(100-250 \mathrm{ml})$ with gentle shaking for various times and temperatures as indicated; in some cases cycloheximide (final concn. $0.2 \mathrm{~mm}$ ) was added after an initial incubation and the incubation was then continued for specified periods of time. The incorporation of labelled amino acids into protein was linear for at least $10 \mathrm{~min}$ in both the reticulocyte and liver cell-free systems.

After incubation, the mixture $(5-6 \mathrm{ml})$ was layered on top of a discontinuous sucrose gradient consisting of $3.5 \mathrm{ml}$ of $0.5 \mathrm{M}$-sucrose in buffer B over $3.5 \mathrm{ml}$ of $1.8 \mathrm{M}$-sucrose in buffer $\mathrm{B}$. To decrease the possibility of contamination of the ribosome preparation by radioactive amino acids, buffer $B$ also contained the appropriate unlabelled amino acid $(10 \mathrm{~mm})$ corresponding to the labelled precursor. After centrifuging for $3 \mathrm{~h}$ at $105000 \mathrm{~g}$ in the $8 \times 25 \mathrm{ml}$ MSE angle rotor, clean polyribosome pellets were obtained.

After removal of the supernatant, the pellets were rinsed several times with cold buffer $B$ and the walls of the centrifuge tubes were dried with absorbent tissue. As required, the ribosome pellets were stored at $-20^{\circ} \mathrm{C}$ or resuspended in an appropriate solution.

Labelling of rat liver nascent proteins in vivo. Albino rats $(150-250 \mathrm{~g}$ body wt.) were starved for $18 \mathrm{~h}$ to deplete liver glycogen, and were then injected intraperitoneally with a labelled amino acid (usually either $0.2 \mu \mathrm{Ci}$ of ${ }^{14} \mathrm{C}$ or $2 \mu \mathrm{Ci}$ of ${ }^{3} \mathrm{H}$ per $\mathrm{g}$ body wt.). The animals were killed 7-10 min later, the livers were rapidly excised, washed in ice-cold buffer $A$ and weighed. All subsequent procedures were carried out at $0-4^{\circ} \mathrm{C}$. Ribosomes were prepared by a modification of the method of Wettstein et al. (1963). The livers were cut into small pieces and homogenized in $2.5 \mathrm{vol}$. of buffer A by using four strokes in a motor-driven glass-Teflon homogenizer. The homogenate was centrifuged at $10000 \mathrm{~g}$ for $10 \mathrm{~min}$ and the white lipid layer at the top was discarded. The postmitochondrial supernatant was collected and a solution of $14.3 \%$ Triton X-100 (0.1 vol.) was added to solubilize the membranes. After centrifuging at $10000 \mathrm{~g}$ for 10 $15 \mathrm{~min}$ the postmitochondrial supernatant $(6-9 \mathrm{ml})$ was layered on top of a discontinuous gradient consisting of $4 \mathrm{ml}$ of $0.5 \mathrm{M}$-sucrose in buffer $B$ over $3 \mathrm{ml}$ of $1.8 \mathrm{M}$-sucrose in buffer $\mathrm{B}$ and centrifuged at $105000 \mathrm{~g}$ for $3 \mathrm{~h}$ in the $8 \times 25 \mathrm{ml}$ MSE angle rotor. The pellets were rinsed several times with buffer $B$, the tubes were wiped clean and the ribosomal pellets were resuspended in an appropriate solution.

Rat liver cell-free system. The method used was similar to the procedure described by Ragnotti $e t$ al. (1969). Rat liver postmitochondrial supernatant, prepared as described above, was centrifuged at 
$105000 \mathrm{~g}$ for $1 \mathrm{~h}$ in the $8 \times 25 \mathrm{ml}$ MSE angle rotor to separate microsomes (microsomal material) from the cell sap. The microsome pellets were rinsed, resuspended in buffer $A^{\prime}$ (approx. $2 \mathrm{ml} / \mathrm{g}$ of original liver) and centrifuged again at $105000 \mathrm{~g}$ for $1 \mathrm{~h}$. The purified microsomes were resuspended in buffer $A^{\prime}$ (about $0.5 \mathrm{ml} / \mathrm{g}$ of liver). The supernatant cell sap from the first ultracentrifugation was passed through Sephadex G-25 (fine grade) in buffer $A^{\prime}$, both to equilibrate and to elute the column $(30 \mathrm{~cm} \times 1.8 \mathrm{~cm}$ diam.). The purified cell sap was stored in small aliquots at $-20^{\circ} \mathrm{C}$.

Incubations were carried out at $37^{\circ} \mathrm{C}$ for specified periods by using mixtures $(10 \mathrm{ml})$ of the following composition: ATP $(20 \mu \mathrm{mol})$, GTP $(2.5 \mu \mathrm{mol})$, potassium phosphoenolpyruvate $(100 \mu \mathrm{mol})$, pyruvate kinase $(500 \mu \mathrm{g})$, all protein aminoacids $(1.25 \mu \mathrm{mol}$ each) except the radioactive precursor, which was added in amounts given for each experiment, Sephadex G-25-purified cell sap ( $2 \mathrm{ml})$ and a suspension of microsomes in buffer $A^{\prime}(4 \mathrm{ml})$.

The incubation was stopped by rapid cooling in ice. Triton X-100 was added and polyribosomes carrying radioactive nascent protein were prepared as described above.

\section{Isolation and fractionation of nascent polypeptides}

The ribosomal pellets were resuspended in the minimum volume $(2-4 \mathrm{ml})$ of $1 \mathrm{M}-\mathrm{KOH}$ (or, in some cases, $0.1 \mathrm{M}$ ) and incubated at $37^{\circ} \mathrm{C}$ for $1 \mathrm{~h}$ to hydrolyse the peptidyl tRNA species (Bresler et al., 1966). The solution was then acidified to $\mathrm{pH} 3.5-4$ by addition of acetic acid. After being centrifuged at approx. $1000 \mathrm{~g}$ for $10 \mathrm{~min}$, the supernatant was found to contain $60-80 \%$ of the radioactivity originally present in the ribosome pellets. No additional radioactive peptides could be solubilized from the ribosomes by prolonged treatment with $\mathrm{KOH}$.

In some cases, the nascent and ribosomal proteins were precipitated by hot $5 \%$ trichloroacetic acid or by hot 1M-perchloric acid (final concentration). The supernatant obtained from the perchloric acid precipitation was neutralized with $\mathrm{KOH}$, potassium perchlorate was removed by centrifuging and the solution was used as a source of labelled 'short' (acid-soluble) nascent chains.

The labelled nascent peptides were fractionated by chromatography at room temperature with Sephadex G-50, the column $(188 \mathrm{~cm} \times 1.8 \mathrm{~cm}$ diam. $)$ being equilibrated and eluted with pyridine-acetic acidwater $(1: 6: 25$, by vol.) at a flow rate of $17-20 \mathrm{ml} / \mathrm{h}$. Fractions $(3 \mathrm{ml})$ were collected and portions $(0.5 \mathrm{ml})$ were used for radioactivity determinations with Bray's (1960) solution $(10 \mathrm{ml})$ in a Tricarb 3001 liquidscintillation spectrometer. For double-label experiments, the channel settings used usually gave an efficiency of $37 \%$ for ${ }^{14} \mathrm{C}$ and $5.5 \%$ for ${ }^{3} \mathrm{H}$, with $26 \%$ spill-over of ${ }^{14} \mathrm{C}$ in the tritium channel. Corrections for quenching were made by internal standardization.

The Sephadex column was calibrated with cytochrome $c$ (82 amino acid residues, mol.wt. 12384), insulin (51 amino acid residues, mol.wt. 5733) and $\left[{ }^{14} \mathrm{C}\right]$ methionine.

\section{Determination of $N$-terminal amino acids}

By dansylation (Gros \& Labouesse, 1969). Approx. $0.5-1.0 \mathrm{mg}$ of protein was dissolved in $0.65 \mathrm{ml}$ of $8 \mathrm{M}$ urea-0.92M-sodium phosphate buffer (pH8.2) and $0.25 \mathrm{ml}$ of dimethylformamide was added, followed by $0.1 \mathrm{ml}$ of $0.2 \mathrm{M}$-dansyl chloride in acetonitrile. The mixture was kept at room temperature for $40 \mathrm{~min}$ with gentle shaking and the dansyl protein was precipitated by adding trichloroacetic acid to a final concentration of $10 \%(w / v)$. The precipitate was centrifuged, washed twice with $1 \mathrm{M}-\mathrm{HCl}$, dissolved in a minimum vol. of $5.7 \mathrm{M}-\mathrm{HCl}$ (usually $1-2 \mathrm{ml}$ ) and hydrolysed in a sealed tube at $110^{\circ} \mathrm{C}$ for $4 \mathrm{~h}$. In some cases internal standards were added. Longer hydrolysis times were avoided in view of their known effect on the recovery of dansyl derivatives. The hydrolysate was evaporated to dryness on a rotary evaporator, the dry residue was dissolved in $0.2 \mathrm{M}$-sodium acetate buffer $(\mathrm{pH} 3.5)$ and extracted into ether $(3 \times 2 \mathrm{ml})$. The extract was evaporated and examined either by descending chromatography on Whatman 3MM paper with the upper phase of butan-1-ol-acetic acidwater ( $4: 1: 5$, by vol.) as solvent or by high-voltage electrophoresis at $\mathrm{pH} 4.4$ on Whatman $3 \mathrm{MM}$ paper with water-acetic acid-pyridine (250:2:1, by vol.). The distribution of radioactivity was determined by cutting the paper into successive strips $(1 \mathrm{~cm} \times 2.5 \mathrm{~cm}$ wide), which were counted for radioactivity in the Tricarb liquid-scintillation spectrometer in $10 \mathrm{ml}$ of scintillator solution [5g of 2,5-diphenyloxazole and $0.3 \mathrm{~g}$ of 1,4-bis-(5-phenyloxazol-2-yl)benzene/1 of toluene].

By Edman degradation. A modification of the method described by Konigsberg (1967) was used. The sample $(5-10 \mathrm{mg})$ was dissolved in $0.5 \mathrm{ml}$ of freshly prepared aq. $50 \%$ pyridine containing $2 \%$ triethanolamine (pH9.5). Methyl isothiocyanate $(0.05 \mathrm{ml})$ was added, the tube was flushed with $\mathrm{N}_{2}$ and closed with a glass stopper. After reaction for $40 \mathrm{~min}$ at $50^{\circ} \mathrm{C}$, the sample was evaporated to dryness in the presence of benzene. Anhydrous trifluoroacetic acid $(1 \mathrm{ml})$ was added and the mixture was heated at $50^{\circ} \mathrm{C}$ for $10 \mathrm{~min}$. The solution was evaporated to dryness, a further $1 \mathrm{ml}$ of trifluoroacetic acid was added and the process repeated. The methylthiohydantoin derivatives were extracted into dichloroethane $(3 \times 2 \mathrm{ml})$. The dichloroethane fractions were combined, evaporated to dryness and dissolved in $1 \mathrm{ml}$ of benzene. Their radioactivity was determined by adding a portion $(0.5 \mathrm{ml})$ to Bray's $(1960)$ solution 
and counting in the Tricarb liquid-scintillation spectrometer. The radioactivity counting efficiency was determined for each individual sample. The efficiency of the Edman degradation was $75 \%$ and all results were corrected accordingly.

\section{Results}

Cell-free incorporation of methionine into nascent globin

Determination of $N$-terminal methionine. A reticulocyte lysate $(32 \mathrm{ml})$ was incubated at $37^{\circ} \mathrm{C}$ for $5 \mathrm{~min}$ with 'lysate mix' $(8 \mathrm{ml})$ containing $\mathrm{L}-\left[2-{ }^{3} \mathrm{H}\right]$ methionine $(104 \mu \mathrm{Ci}$; sp. radioactivity $540 \mathrm{Ci} / \mathrm{mol})$.

The purified ribosome fraction $(53.6 \mathrm{mg})$ was resuspended in $0.1 \mathrm{M}-\mathrm{KOH}(4 \mathrm{ml})$ and after $1 \mathrm{~h}$ at $37^{\circ} \mathrm{C}$ the labelled nascent peptides were precipitated together with unlabelled ribosomal proteins, by perchloric acid. The precipitate was dansylated, hydrolysed with $\mathrm{HCl}$ and the dansyl derivatives were chromatographed as described in the Materials and Methods section. The chromatographic separation of dansylmethionine from methionine and methionine sulphone is shown in Fig. 1. Fraction nos. 33-48 (dansylmethionine) contained 782c.p.m. and frac-

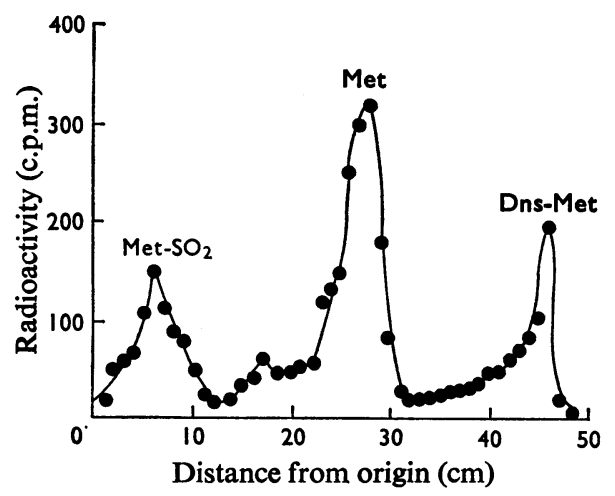

Fig. 1. Presence of $N$-terminal methionine on nascent protein synthesized by a reticulocyte lysate

A reticulocyte lysate was incubated for $5 \mathrm{~min}$ at $37^{\circ} \mathrm{C}$ with $\mathrm{L}-\left[2-{ }^{3} \mathrm{H}\right]$ methionine $(104 \mu \mathrm{Ci}$; sp. radioactivity $540 \mathrm{Ci} / \mathrm{mol})$. The ribosomes were isolated, treated with alkali and the protein was precipitated with perchloric acid. After dansylation, the protein was hydrolysed with $\mathrm{HCl}$ and the hydrolysate chromatographed with added dansylmethionine (Dns-Met), methionine and methionine sulphone (Met-SO $\left.{ }_{2}\right)$ as markers. The radioactivity in methionine + methionine sulphone fractions (nos. 1-32) was 2825c.p.m., that in dansylmethionine fractions (nos. 33-48) 782 c.p.m. The counting efficiency was approx. $5 \%$. tion nos. 1-32 (methionine and methionine sulphone) 2825 c.p.m., giving a value of $21.7 \%$ for $N$-terminal methionine. If allowance is made for the loss of dansylmethionine during acid hydrolysis, which was determined to be approx. $20 \%$, a corrected figure of $27.1 \% N$-terminal methionine is obtained.

The complete amino acid sequence of both the $\alpha$ chain and $\beta$ chain of rabbit haemoglobin is known and methionine occurs at positions 32 and 55 respectively (Braunitzer et al., 1968). On the assumption that ribosomes are uniformly distributed on messenger RNA (Hunt et al., 1968) and that $\alpha$ and $\beta$ chains are equally labelled in the lysate, the relationship between the percentage of labelled $N$-terminal methionine present in an equimolar mixture of nascent globin $\alpha$ and $\beta$ peptides and the length of nascent globin chains at which removal of the $N$ terminal methionine takes place is given by the equation:

$$
\% N \text {-terminal methionine }=100 n /(a+n)
$$

where $n=$ number of peptides containing $N$-terminal methionine and $a=$ total number of internal methionine residues in nascent peptides. For globin, the short nascent $\alpha$ chains up to and including amino acid residue 31 have no internal methionine and hence $a=141-31=110$. Similarly, for nascent $\beta$ chains $a=146-54=92$. Fig. 2 gives the calculated values for the percentage of $N$-terminal methionine expected to be present in an equimolar population of nascent $\alpha$ chains, $\beta$ chains or a mixture of $\alpha$ chains and $\beta$ chains when the $N$-terminal methionine is removed at various stages of peptide elongation ranging from dipeptides $(n=1)$ to complete chains $(n=141$ for $\alpha$ chains and 146 for $\beta$ chains). A value of $27.1 \%$ for $N$-terminal methionine corresponds to the presence of this amino acid on nascent peptides up to a chain length of 38 residues $(n=37)$. Since precipitation of the shortest peptides by perchloric acid is probably not quantitative, it is likely that this method gives a minimum estimate of the chain length at which cleavage of the $\mathrm{N}$-terminal methionine takes place.

Fractionation of nascent globin peptides. Further information about the relationship of peptide size and cleavage of $N$-terminal methionine was obtained by fractionating nascent globin peptides according to chain length on Sephadex G-50. The methionine content of various fractions was investigated by two methods. First, nascent peptides were labelled with methionine and a suitable second amino acid to detect removal of the $N$-terminal methionine by an increase in the amino acid/methionine ratio as peptidechain elongation proceeds. Tyrosine was selected as an appropriate amino acid for the purpose of this experiment, since it occurs in relatively few positions of globin, namely $\alpha 24, \alpha 42, \alpha 140, \beta 35, \beta 130$ and $\beta 145$. The changes in the tyrosine/methionine ratio to be expected as a result of loss of the $N$-terminal 


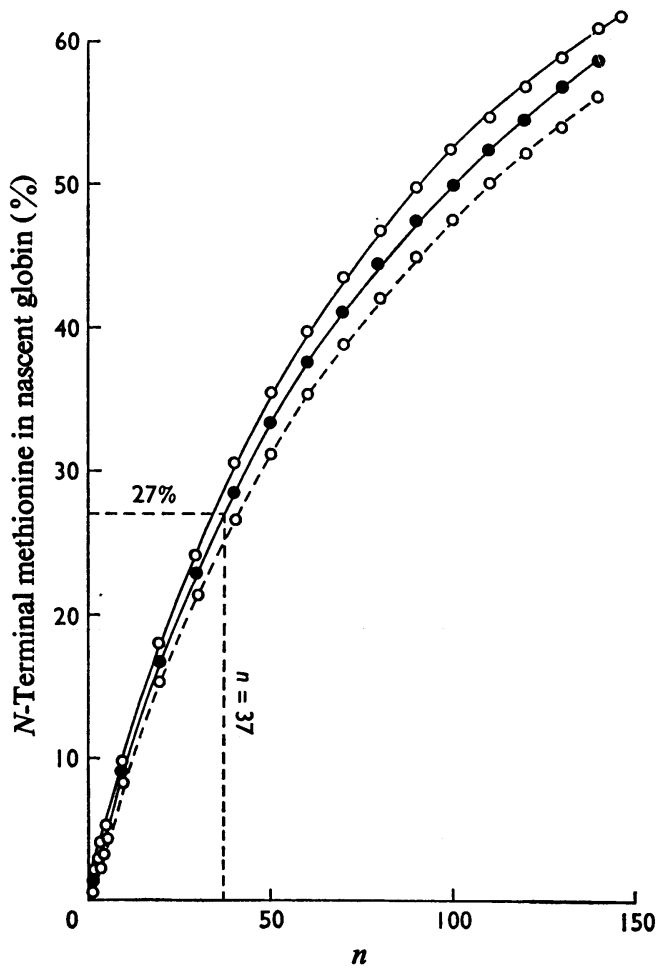

Fig. 2. Relationship between amount of $N$-terminal methionine in rabbit nascent globin chains and size of nascent peptides from which the $N$-terminal methionine is cleaved

The amount of $N$-terminal methionine, calculated for an equimolar mixture of nascent $\alpha$ chains $(0--0)$, nascent $\beta$ chains $(0-0)$ or a mixture of the two chains (-)) from the known amino acid sequences of rabbit globin, is plotted against the chain length at which removal of the $N$-terminal methionine takes place. $n$, Number of peptide bonds in nascent chain from which the $N$-terminal methionine is cleaved.

methionine are shown in Table 1. Nascent peptides of chain length shorter than 24 residues contain no tyrosine. Peptides of intermediate size have a tyrosine/methionine ratio of between 0.33 and 1 and for any given size-class removal of the terminal methionine gives rise to a two- to three-fold increase in this ratio, except that for peptides containing 24-31 amino acid residues the theoretical change is even greater, namely from 0.5 to $\infty$.

In this experiment, a reticulocyte lysate $(20 \mathrm{ml})$ was incubated at $30^{\circ} \mathrm{C}$ for $5 \mathrm{~min}$ with the usual 'lysate mix' $(5 \mathrm{ml})$ containing $\mathrm{L}-\left[\right.$ methyl- $\left.{ }^{3} \mathrm{H}\right]$ methionine $(250 \mu \mathrm{Ci}, \quad 7.6 \mathrm{Ci} / \mathrm{mmol})$, L- $\left[{ }^{14} \mathrm{C}\right]$ tyrosine $(15.5 \mu \mathrm{Ci}$, $513 \mathrm{Ci} / \mathrm{mol}$ ) and an amino acid mixture minus methionine and tyrosine, followed by incubation for a further $0.5 \mathrm{~min}$ at $30^{\circ} \mathrm{C}$ in the presence of $0.2 \mathrm{~mm}$ cycloheximide. A polyribosome pellet $(17.2 \mathrm{mg})$ was obtained, nascent peptides were released by the standard treatment with $1 \mathrm{M}-\mathrm{KOH}$ and fractionated by chromatography on Sephadex G-50 (Fig. 3a). The Sephadex column was calibrated with cytochrome $c$ and insulin, additional reference points being obtained from the positions of free amino acids, the smallest tyrosine-containing nascent globin peptides and the smallest arginine-containing nascent globin peptides. The latter were derived from a similar incubation (results not shown) of a lysate with labelled $\left[{ }^{14} \mathrm{C}\right]$ arginine and $\left[{ }^{3} \mathrm{H}\right]$ methionine.

In Fig. 3(b), the calculated tyrosine/methionine ratios of peptides of different chain lengths are compared with the observed values, which were determined on labelled nascent peptides fractionated by chromatography with Sephadex G-50. The results show that nascent globin peptides containing more than 55 amino acids have a tyrosine/methionine ratio of approx. 1.5, in good agreement with the calculated value for peptides lacking $N$-terminal methionine, although the exact numerical correspondence between the observed and theoretical ratios was unexpected, since it depends on the tyrosine and methionine pools in the lysate being identical in size. On the other hand, shorter peptides, up to a chain length of approx. 47 amino acids, have tyrosine/ methionine ratios close to the theoretical values for peptides with $N$-terminal methionine. Intermediate peptides ranging in size from 47 to 55 amino acid residues have tyrosine/methionine ratios which increase with increasing chain length, reaching a maximum of 2, suggesting that removal of $N$-terminal methionine starts when nascent globin chains have reached a length of approx. 45 amino acids but is not complete until the chains have elongated to approx. 55-60 residues. Essentially comparable changes in the methionine/arginine ratio of nascent peptides were observed in a similar experiment in which $\left[{ }^{14} \mathrm{C}\right]$ arginine and $\left[{ }^{3} \mathrm{H}\right]$ methionine were used as the labelled amino acids.

In agreement with the observed changes in the methionine/tyrosine ratios of fractionated nascent globin peptides, there was a marked change in the $N$ terminal amino acid content at a chain length of approx. 50 residues. Thus $N$-terminal amino acid analysis by Edman degradation of nascent peptides that had been previously labelled with either methionine or valine and fractionated showed that the $N$ terminal amino acid of short peptides is methionine, whereas long peptides contained $N$-terminal valine (Table 2). The percentages of $N$-terminal methionine in peptide fractions nos. 4 and 5 approximate to the theoretical values. Fraction no. 3 (chain length 45-52 residues) contains $N$-terminal methionine corresponding to approx. $45 \%$ of the theoretical 
Table 1. Theoretical tyrosine/methionine ratios of an equimolar mixture of rabbit nascent globin $\alpha$ and $\beta$ peptides

The calculation is based on the known positions of tyrosine and methionine in the globin $\alpha$ and $\beta$ chains (Braunitzer et al., 1968). To retain the same numbering of amino acid residues in nascent peptides and completed globin chains the contribution of the $N$-terminal methionine to peptide chain length is omitted.

Size of nascent peptide

(no. of amino acids)

Positions of tyrosine

Positions of methionine

$\begin{array}{ccccccccc}<24 & 24-31 & 32-34 & 35-41 & 42-54 & 55-129 & 130-139 & 140-144>144 \\ \begin{array}{c}N \text {-terminal } \\ (\alpha, \beta)\end{array} & \alpha 24 & & \beta 35 & \alpha 42 & & \beta 130 & \alpha 140 & \beta 145 \\ 0 & & \alpha 32 & & & \beta 55 & & & \\ 0 & 0.5 & 0.33 & 0.67 & 1 & 0.75 & 1 & 1.25 & 1.67 \\ 0 & \infty & 1 & 2 & 3 & 1.5 & 2 & 2.5 & 3.0\end{array}$

Tyrosine/methionine ratio:

(a) of peptides containing

$N$-terminal methionine

(b) of peptides which have

lost $N$-terminal

methionine

value, but the most marked change first becomes apparent in fraction no. 2 (chain length 53-69 residues), which contains almost no methionine. The experiment with labelled valine gave complementary results, $N$-terminal valine first appearing in substantial amounts in fraction no. 2 (chain length 54-76 residues). These results suggest that removal of the $N$-terminal methionine takes place when nascent globin peptides have elongated to a chain length of approx. 47-53 amino acid residues.

Effect of cycloheximide. The possibility that removal of the $N$-terminal methionine residue from nascent globin may be related to the rate of polypeptide chain elongation was investigated by comparing the nascent globin peptides from a control lysate incubated with $\left[{ }^{3} \mathrm{H}\right]$ methionine for $2 \mathrm{~min}$ at $37^{\circ} \mathrm{C}$ with those from a lysate that was incubated for an additional $3 \mathrm{~min}$ in the presence of $0.2 \mathrm{~mm}$-cycloheximide, an inhibitor of the translocation reaction (McKeehan \& Hardesty, 1969), and $\left[{ }^{14} \mathrm{C}\right]$ leucine (Fig. 4). The nascent globin peptides were released by treatment of the polyribosome fraction with alkali, fractionated on Sephadex G-50 and analysed for $\mathrm{N}$-terminal methionine by the Edman degradation.

In this system, protein synthesis in the presence of cycloheximide was markedly decreased but not completely inhibited, as shown by the incorporation of small amounts of labelled leucine into nascent polypeptides during the $3 \mathrm{~min}$ incubation in the presence of the inhibitor. Cycloheximide appears to have little effect on the amount and pattern of label in the long nascent peptides from which the $N$-terminal methionine has already been cleaved, as shown by the almost unchanged radioactivity profile of the column effluent up to approx. $230 \mathrm{ml}$, corresponding to a chain length of more than 50 amino acid residues. A marked decrease, however, was observed after the $3 \mathrm{~min}$ incubation in the presence of cycloheximide in the amount of labelled nascent peptides of chain length 30-50 (effluent volume $230-300 \mathrm{ml}$ ), and an almost identical result (not shown) was obtained when the incubation with cycloheximide was prolonged to $10 \mathrm{~min}$.

\section{Initiation of protein synthesis in rat liver}

$N$-Terminal amino acids of rat liver proteins. Rat liver synthesizes a mixture of different proteins. A major component is serum albumin, which represents about $30 \%$ of total liver-protein synthesis (Campbell, 1964) and is known to contain glutamic acid as the $N$-terminal amino acid residue (Sargent \& Campbell, 1965). There are also 85 glutamic acid and six methionine internal residues in the protein.

The $N$-terminal amino acids of proteins present in rat liver postmicrosomal supernatant and in ribosomal pellets were investigated (Koffer-Gutmann, 1972) by the dansylation method. Glutamic acid, glycine and at least one of the neutral amino acids, alanine, methionine, serine and proline, which were, however, not sufficiently resolved, were found to be the predominant $N$-terminal amino acids in rat livercell sap. The proteins of the ribosomal pellets contained relatively large amounts of $N$-terminal glutamic acid and aspartic acid, glycine and methionine sulphone, the last-named probably originating by oxidation of dansylmethionine during acid hydrolysis of the protein. Neutral amino acids (alanine, methionine, proline and serine), which again were not completely resolved, were also present. Thus the $N$-terminal amino acid pattern of rat liver proteins seems to be complex.

The possible presence of $N$-terminal glutamic acid in nascent chains of rat liver proteins was investigated by labelling the proteins in a cell-free system with $\left[{ }^{14} \mathrm{C}\right]$ glutamic acid $(0.5 \mu \mathrm{Ci} / \mathrm{ml}, 260 \mathrm{Ci} / \mathrm{mol})$ followed by the isolation of ribosomal pellets and dansylation of hot trichloroacetic acid-insoluble peptides as described in the Materials and Methods section. 

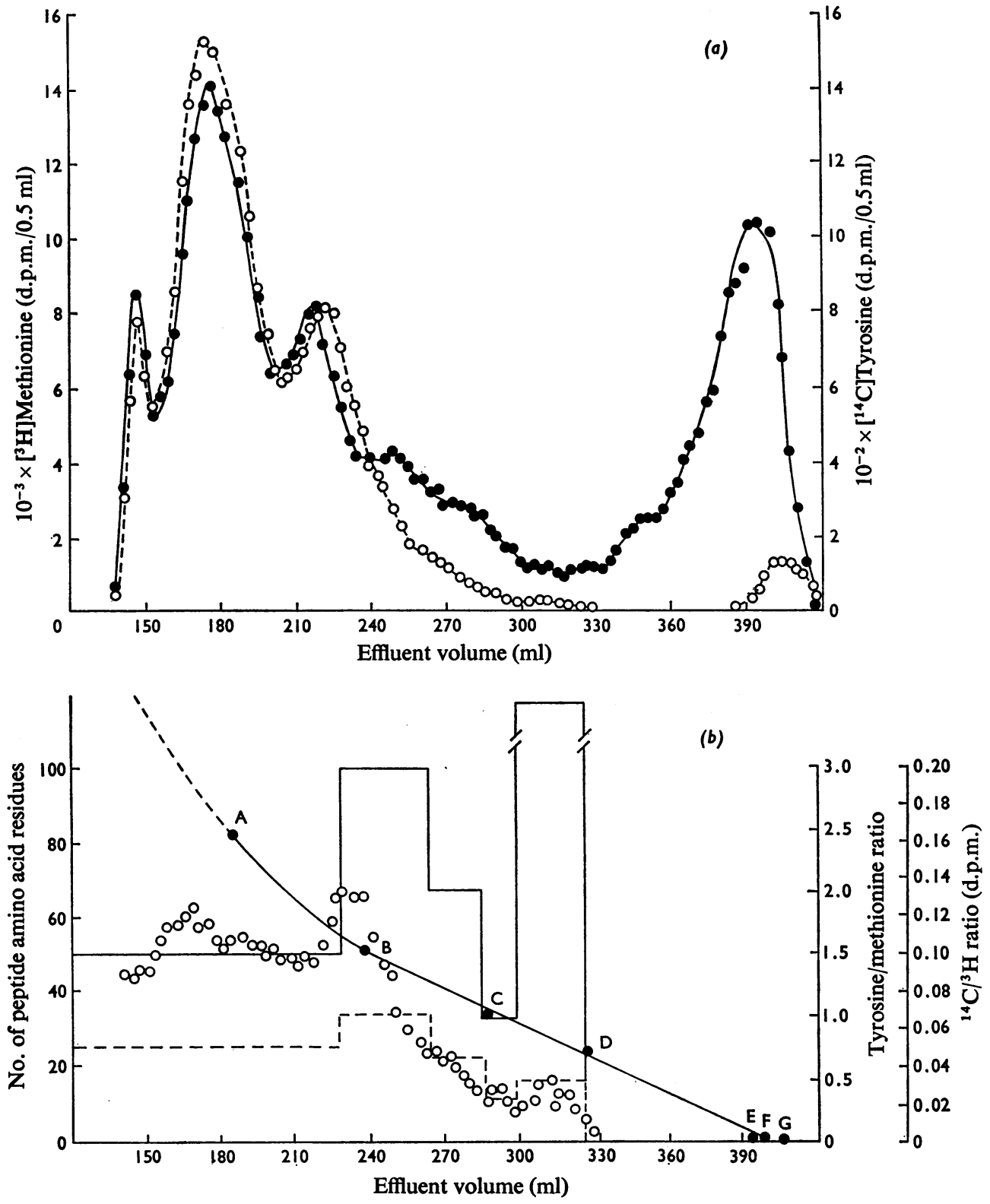

Fig. 3. Methionine/tyrosine ratio of nascent globin peptides of increasing chain length

A reticulocyte lysate $(20 \mathrm{ml})$ was incubated for $5 \mathrm{~min}$ at $30^{\circ} \mathrm{C}$ with $\mathrm{L}-\left[\right.$ methyl $\left.-{ }^{3} \mathrm{H}\right]$ methionine and $\mathrm{L}-\left[{ }^{14} \mathrm{C}\right]$ tyrosine. At the end of the incubation, cycloheximide was added to a final concentration of $0.2 \mathrm{~mm}$ and, after $0.5 \mathrm{~min}$ at $30^{\circ} \mathrm{C}$, the nascent peptides were obtained and chromatographed on Sephadex G-50. Fractions $(3 \mathrm{ml})$ were collected and radioactivity was assayed on $0.5 \mathrm{ml}$ samples. (a) Radioactivity profile: $\bullet,\left[{ }^{3} \mathrm{H}\right]$ methionine; $\circ,\left[{ }^{14} \mathrm{C}\right]$ tyrosine. (b) Tyrosine/methionine ratios for each fraction (O) and the theoretical ratios for nascent globin peptides of various sizes containing either $N$-terminal and internal methionine residues (----) or internal methionine only (-). Reference points: A, cytochrome $c$ (82 amino acid residues); B, insulin (51 amino acid residues); C, smallest arginine-containing globin peptides (32 amino acid residues); $\mathbf{D}$, smallest tyrosine-containing globin peptides (24 amino acid residues); E, free methionine; F, free arginine; G, free tyrosine. 


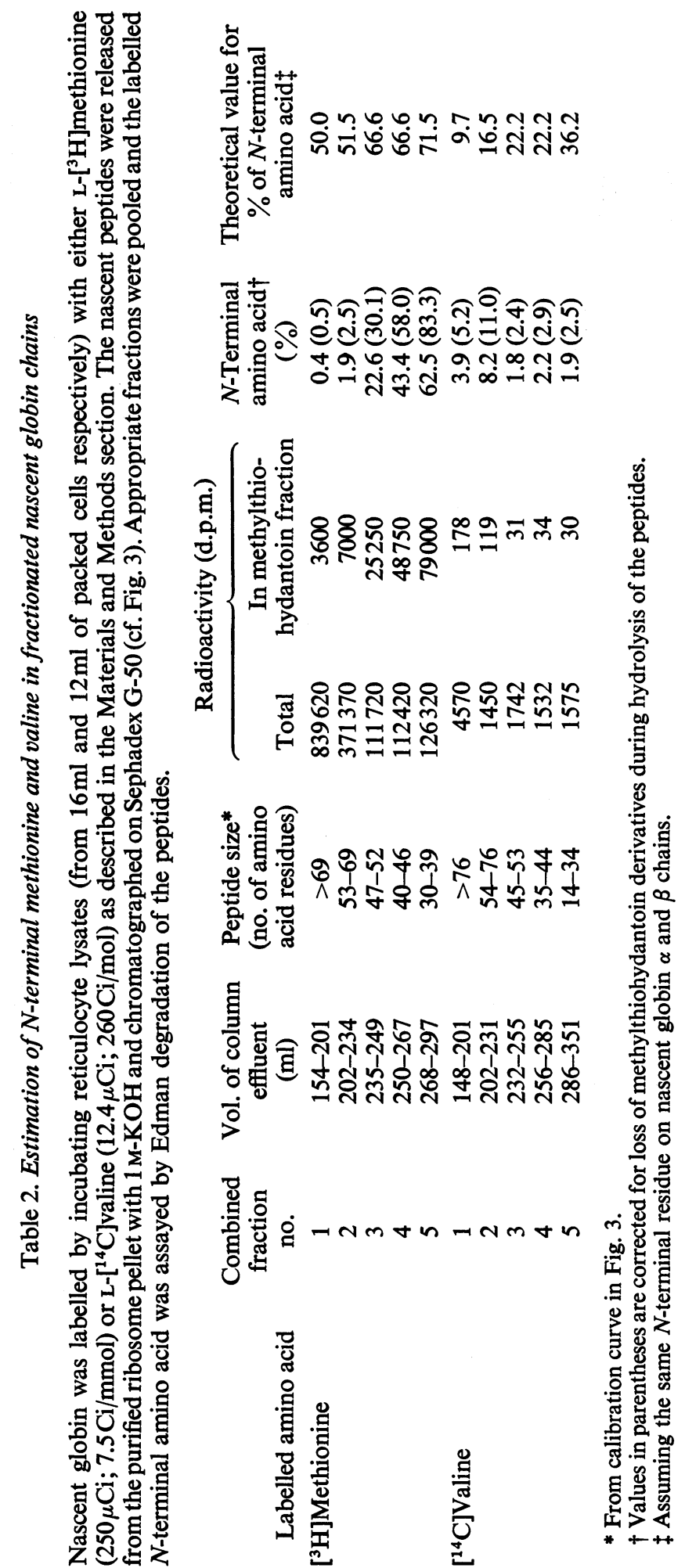



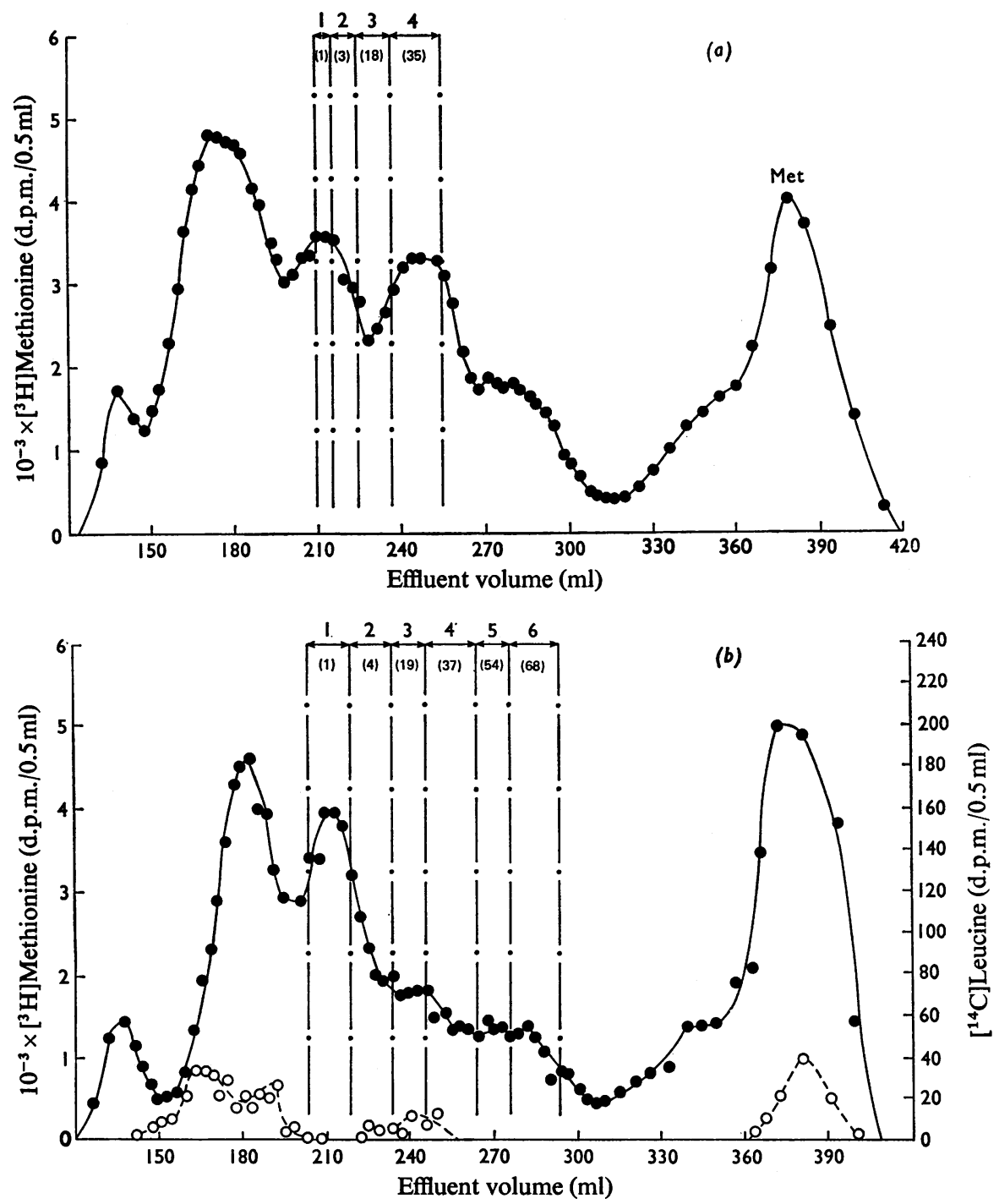

Fig. 4. Effect of cycloheximide on the size distribution of nascent globin peptides

Two reticulocyte lysates $(12 \mathrm{ml})$ were incubated at $37^{\circ} \mathrm{C}$ for $2 \mathrm{~min}$ with $\mathrm{L}-\left[\right.$ methyl $\left.{ }^{3} \mathrm{H}\right] \mathrm{methionine}(150 \mu \mathrm{Ci}$; $7.6 \mathrm{Ci} / \mathrm{mmol})$ and the usual amino acid mixture, but no unlabelled methionine or leucine. The control $(a)$ was used directly for isolation and fractionation of nascent peptides; the other lysate $(b)$ was incubated for a further $1 \mathrm{~min}$ with $0.2 \mathrm{~mm}$-cycloheximide and then for a further $2 \mathrm{~min}$ after addition of $\mathrm{L}-\left[{ }^{14} \mathrm{C}\right] \mathrm{leucine}(7.5 \mu \mathrm{Ci} ; 331 \mathrm{mCi} / \mathrm{mmol})$ before isolation and fractionation of the nascent peptides. The peptides were fractionated on a Sephadex G-50 column in the usual way and assayed for radioactivity ( $\bullet)$. Selected fractions were pooled $(a, 1-4, b, 1-6)$ and used to determine the number of $N$-terminal methionine residues by the Edman method, the values obtained being shown in parentheses.

Table 3 (Expts. 1 and 2) shows that only a small proportion of the glutamic acid in rat liver nascent protein is present at the $N$-terminus. The results of Expt. 3 were obtained by a similar examination of dansylated nascent peptides labelled by $\left[{ }^{14} \mathrm{C}\right]-$ glutamic acid in vivo. In this case, the dansylated proteins were hydrolysed by a protease to avoid the destruction of labile derivatives of glutamic acid by 


\section{Table 3. Proportion of glutamic acid at the $N$-terminal position of rat liver nascent chains labelled with} $\left[{ }^{14} \mathrm{C}\right]$ glutamic acid

In Expts. 1 and 2, nascent peptides were labelled for $10 \mathrm{~min}$ in a cell-free system as described in the Materials and Methods section. $\left[{ }^{14} \mathrm{C}\right]$ Glutamic acid $(260 \mathrm{Ci} / \mathrm{mol})$ was present in the incubation mixture $(0.5 \mu \mathrm{Ci} / \mathrm{ml})$. The trichloroacetic acid-precipitable labelled peptides from the ribosomal pellets were dansylated, hydrolysed with acid and the dansyl derivatives in the ether-extractable fractions of the hydrolysate were examined by paper electrophoresis at pH4.4. In Expt. 3, nascent peptides were labelled in vivo with $\left[{ }^{14} \mathrm{C}\right] \mathrm{glutamic}$ acid $(260 \mathrm{Ci} / \mathrm{mol} ; 0.2 \mu \mathrm{Ci} / \mathrm{g}$ body wt.), the acid-precipitable peptides from ribosomal pellets were dansylated and hydrolysed by protease (Sigma Chemical Co.) $(3 \mathrm{mg} / \mathrm{ml})$ at $37^{\circ} \mathrm{C}$ for $42 \mathrm{~h}$ in $5 \mathrm{ml}$ of $0.1 \mathrm{M}$-triethylamine-acetate buffer, $\mathrm{pH}$ 7.7. The hydrolysate was examined by descending chromatography as described in the Materials and Methods section.

$\begin{array}{cccc}\text { Expt. no. } & \begin{array}{c}\text { Total radioactivity in } \\ \text { hydrolysate (d.p.m.) }\end{array} & \begin{array}{c}\text { Radioactivity corresponding } \\ \text { to dansylglutamic acid (d.p.m.) }\end{array} & \begin{array}{c}N \text {-Terminal } \\ \text { glutamic acid (\%) }\end{array} \\ 1 & 87500 & 925 & 1.05 \\ 2 & 140000 & 410 & 0.29 \\ 3 & 6248 & 40 & 0.64\end{array}$

the drastic conditions of hydrolysis with $\mathrm{HCl}$. Specifically, the experiment was designed to detect the presence of pyrrolidonecarboxylic acid, which has been considered to have a role in the initiation of protein synthesis (Bernfield \& Nestor, 1968). The radioactivity found to be associated with pyrrolidonecarboxylic acid was $3.8 \%$ of the total radioactivity incorporated. However, the possibility that cyclization of glutamic acid or glutamine (Blombäck, 1967) may have occurred at some stage of the procedure could not be rigorously excluded and no further studies of pyrrolidonecarboxylic acid were carried out.

To investigate whether methionine is present at the $N$-terminal position of rat liver nascent chains, the proteins were pulse-labelled with $\left[{ }^{14} \mathrm{C}\right]$ methionine $(60 \mathrm{Ci} / \mathrm{mol})$. The amounts of $N$-terminal methionine on acid-precipitable nascent chains and also on the completed liver proteins from the cell sap were determined by the dansylation method and by the Edman degradation respectively. Whereas $N$-terminal methionine amounted to $3.3 \%$ of the total $\left[{ }^{14} \mathrm{C}\right]-$ methionine incorporated into the cell-sap proteins, rat liver nascent peptides contained $11.6 \%$ of $\mathrm{N}$ terminal methionine. Similarly, in another experiment the nascent chains were labelled in vitro with $\left[{ }^{3} \mathrm{H}\right]-$ methionine $(2.7 \mu \mathrm{Ci} / \mathrm{ml}, 540 \mathrm{Ci} / \mathrm{mol})$ and the proportion of $N$-terminal methionine was found to be $12.6 \%$ (Fig. 5).

The results obtained with acid-precipitable rat liver nascent chains are summarized in Table 4, which shows that methionine is a major $N$-terminal group of the nascent proteins of rat liver.

Fractionation of rat liver nascent chains by Sephadex $G-50$. Labelled ribosomes were obtained from the livers of rats that had been injected with $\left[{ }^{3} \mathrm{H}\right]$ methionine ( $5.2 \mathrm{Ci} / \mathrm{mmol}) ; 2 \mu \mathrm{Ci} / \mathrm{g}$ body $\mathrm{wt}$.) and the nascent peptides were released by $\mathrm{KOH}$ treatment. The fractionation of these peptides by Sephadex G-50 and the results of the Edman degradation of peptides in five combined fractions are shown in Fig. 6 and Table 5 respectively. It is evident that much radioactivity was present in the form of free methionine. Free amino acids, however, were well separated from the peptides and the results show clearly that the percentage of $N$-terminal methionine increases with decreasing size of nascent peptides. $N$-Terminal methionine appears to be present mainly on comparatively short nascent chains containing up to about 65 amino acid residues (fraction nos. 4 and 5, Table 5; elution volume approx. $200-300 \mathrm{ml}$ ), although somelonger chains may also contain this $N$-terminal group.

\section{Discussion}

\section{Analysis of $\mathrm{N}$-terminal methionine in nascent globin}

When acid-precipitable nascent peptides synthesized by the rabbit reticulocyte lysate in the presence of labelled methionine were analysed for $N$-terminal methionine by the dansylation method a value of $27.1 \%$ was obtained after correction for losses during acid hydrolysis. On the basis of certain assumptions discussed in the Results section this value would correspond to the presence of methionine on peptides up to a chain length of approx. 38 amino acid residues (Fig. 2). Apart from the possibility that the cell-free incorporation into nascent globin $\alpha$ and $\beta$ chains may not be equal or uniform with respect to chain length, this method is likely to underestimate the amount of $N$-terminal methionine because very short globin peptides, which would contain most of the $N$-terminal methionine, are not precipitated by acid. We therefore decided to investigate the $N$-terminal end groups of nascent globin peptides after fractionation according to chain length.

Edman degradation of nascent peptides, previously fractionated on a Sephadex G-50 column, showed 
(Table 2) that very little $N$-terminal methionine was present in peptides eluting in an effluent volume corresponding to sizes greater than 52 amino acid residues. However, valine, which is the $N$-terminal residue of both globin $\alpha$ and $\beta$ chains, was not detected to any significant extent in nascent chains shorter than 54 residues. These experiments indicate a change in the $N$-terminal amino acid residue during polypeptide-chain elongation consistent with cleavage of the original $N$-terminal methionine at a chain length of approx. 50 residues. The observed increase in the tyrosine/methionine radioactivity ratio of nascent peptides at this chain length also agrees with that expected for removal of $N$-terminal methionine at this stage of peptide-chain elongation (Fig. 3).

These estimates of peptide size depend critically on the efficiency of the fractionation procedure in separating nascent peptides, as well as on the reliability of the Edman degradation procedure. The results of the Edman degradation of the very short nascent chains might have been obscured by the unspecific extraction of short chains into the organic phase, but for the intermediate-size and long chains this possibility can be excluded since in the double-label experiments the methylthiohydantoin fraction did not contain any radioactivity corresponding to an internal amino acid. As regards the fractionation procedure, it is possible that short nascent peptides could aggregate either with themselves or with long chains and thus be eluted from the Sephadex column in the same effluent volume as longer peptides, giving rise to an overestimate of the size of peptides from which methionine is cleaved. Such an aggregation of short chains appears to be excluded, however, because the results obtained with fractionated nascent chains labelled with $\left[{ }^{14} \mathrm{C}\right]$ valine were complementary to those obtained with peptides labelled with $\left[{ }^{3} \mathrm{H}\right]-$ methionine (Table 2), i.e. after chromatography with Sephadex G-50 peptide fractions contained either methionine or valine as the $N$-terminal residue but not both in significant amounts. Moreover, the percentage of $N$-terminal methionine steadily decreased with increasing peptide size, whereas aggregation of short chains would have resulted in an unexpected increase in the proportion of $N$-terminal methionine.

Although the fractionation procedure thus appears to be reliable and efficient, some overlap of peptides of different sizes is unavoidable. It is not possible therefore to differentiate precisely between mechanisms involving cleavage of the initiating methionine when a specific chain length is reached, or removal of methionine from peptides within a certain size range. In the latter case, the range is likely to be relatively narrow, possibly 47-55 amino acid residues, as indicated by the results of the Edman degradation.

If all globin chains are initiated by methionine, and if an equal number of nascent globin $\alpha$ and $\beta$ peptides are present on polyribosomes, the percentage of $N$ terminal methionine just before cleavage, i.e. in nascent chains containing 32-50 amino acid residues,

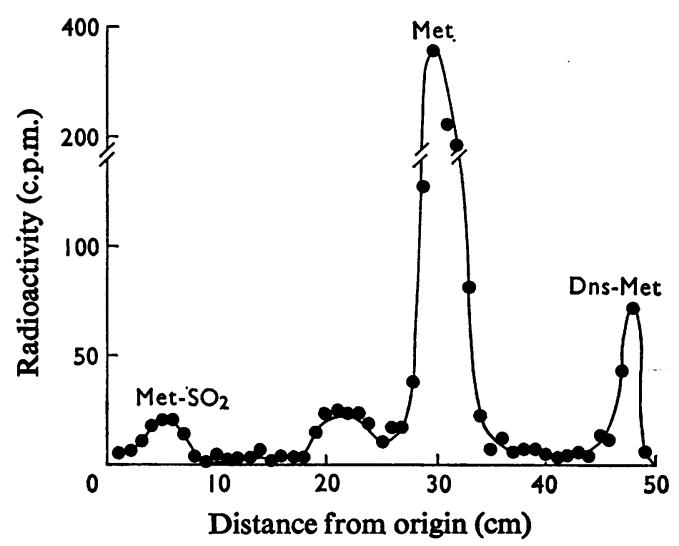

Fig. 5. Presence of $N$-terminal methionine in liver nascent protein

A mixture containing washed microsomes (from $32 \mathrm{~g}$ of rat liver), cell sap ( $8 \mathrm{ml}$ ) purified by chromatography on Sephadex G-25, L-[2- $\left.{ }^{3} \mathrm{H}\right]$ methionine $(108 \mu \mathrm{Ci}$; $540 \mathrm{Ci} / \mathrm{mol}$ ) and the other components of the cellfree system described in the Materials and Methods section was incubated for $10 \mathrm{~min}$ at $37^{\circ} \mathrm{C}$. The ribosomes were sedimented through $0.5 \mathrm{M}$-sucrose $(4 \mathrm{ml})$ and $1.8 \mathrm{M}$-sucrose $(3 \mathrm{ml})$, resuspended in $0.01 \mathrm{M}-\mathrm{KOH}$ $(8 \mathrm{ml})$ and kept at $37^{\circ} \mathrm{C}$ for $1 \mathrm{~h}$. Protein was precipitated by $2 \mathrm{M}$-perchloric acid $(8 \mathrm{ml})$, dansylated and hydrolysed with $\mathrm{HCl}$. The hydrolysate was chromatographed as described in Fig. 1. The counting efficiency was approx. $5 \%$. After correcting for $20 \%$ loss of dansyl derivative, the amount of radioactive dansylmethionine (157c.p.m.) corresponded to $12.6 \%$ $N$-terminal labelling.

Table 4. Proportion of $\mathrm{N}$-terminal glutamic acid and methionine in rat liver protein

For details see Table 3, Fig. 5 and the text.

Protein fraction

Nascent protein Cell-sap protein

$\begin{array}{cc}\text { Glutamic acid (\%) } & \text { Methionine (\%) } \\ 0.66 & 12.1 \\ \text { Not determined } & 3.3\end{array}$

Vol. 134 


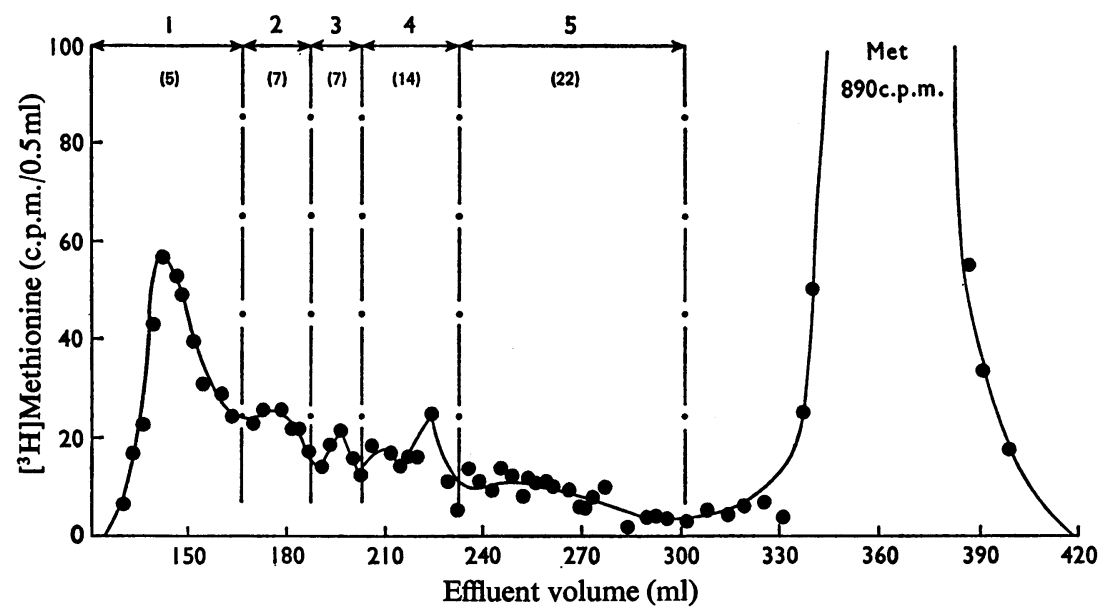

Fig. 6. Fractionation of liver nascent peptides labelled by $\mathrm{L}-\left[\right.$ methyl $\left.{ }^{3} \mathrm{H}\right]$ methionine in vivo

Rat liver nascent protein was labelled by the incorporation in vivo of $\mathrm{L}-\left[\right.$ methyl $\left.{ }^{3} \mathrm{H}\right] \mathrm{methionine.} \mathrm{The} \mathrm{ribosomes} \mathrm{were}$ isolated, nascent chains released by alkali and chromatographed on Sephadex G-50. Fractions were combined as shown (1-5) and analysed by the Edman method, the percentage of $N$-terminal methionine being given in parentheses.

\section{Table 5. Edman degradation of nascent peptides from rat liver}

Labelled nascent peptides were obtained by injecting $\left[{ }^{3} \mathrm{H}\right]$ methionine into a rat, removing the liver $7 \mathrm{~min}$ later, isolating the ribosomal fraction and treating it with alkali as described in the Materials and Methods section. From $86 \mathrm{mg}$ of ribosomes $\left(1.04 \times 10^{6}\right.$ d.p.m. $) 68 \%$ of radioactivity $\left(0.71 \times 10^{6}\right.$ d.p.m. $)$ was released by alkali and chromatographed on Sephadex G-50 (see Fig. 6). Appropriate fractions were combined and subjected to the Edman degradation. Values in parentheses are corrected for losses during preparation of the methylthiohydantoin derivative.

$\begin{array}{ccc}\begin{array}{c}\text { Combined } \\ \text { fractions }\end{array} & \begin{array}{c}\text { Effluent vol. } \\ (\mathrm{ml})\end{array} & \begin{array}{c}\text { Radioactivity in } \\ \text { column fraction } \\ (\text { d.p.m.) }\end{array} \\ 1 & 118-165 & 27900 \\ 2 & 166-186 & 9000 \\ 3 & 187-201 & 6800 \\ 4 & 202-231 & 7430 \\ 5 & 233-300 & 16100\end{array}$

Radioactivity in
methylthiohydantoin
derivative
(d.p.m.)
965
440
340
760
2610

Methionine in
$N$-terminal position
$(\%)$
$3.4(4) 5)$
$4.9(6.5)$
$5.0(6.7)$
$10.2(13.6)$
$16.2(21.6)$

should be $66.7 \%$ (Fig. 7). The experimentally determined values (Table 2 ) of 83 and $58 \%$ for peptide fractions with $30-39$ residues and $40-46$ residues respectively are in reasonable agreement with theory. Although there is some uncertainty about the precise proportion of globin $\alpha$ and $\beta$ chains on polyribosomes, the most recent work indicates that in globin synthesis there is no rate-limiting step during chain elongation (Hunt et al., 1968; Luppis et al., 1970), but that there may be a $10-20 \%$ excess of nascent $\beta$ chains (Hunt et al., 1969). Even the presence of a $20 \%$ excess of nascent $\beta$ chains, however, would result in the calcu- lated amount of $N$-terminal methionine in the relevant peptide fraction (32-50 residues) being increased from $66.7 \%$ to only $68.6 \%$.

We conclude that in our experiments cleavage of the $N$-terminal methionine residue occurred when the nascent globin peptides had elongated to a chain length of approx. 50 amino acid residues. On the other hand, after labelling of intact reticulocytes $N$ terminal methionine was detected only in very short nascent chains up to a length of less than 30 residues (Jackson \& Hunter, 1970; Yoshida et al., 1970). The absence of $N$-terminal methionine in intact reticulo- 


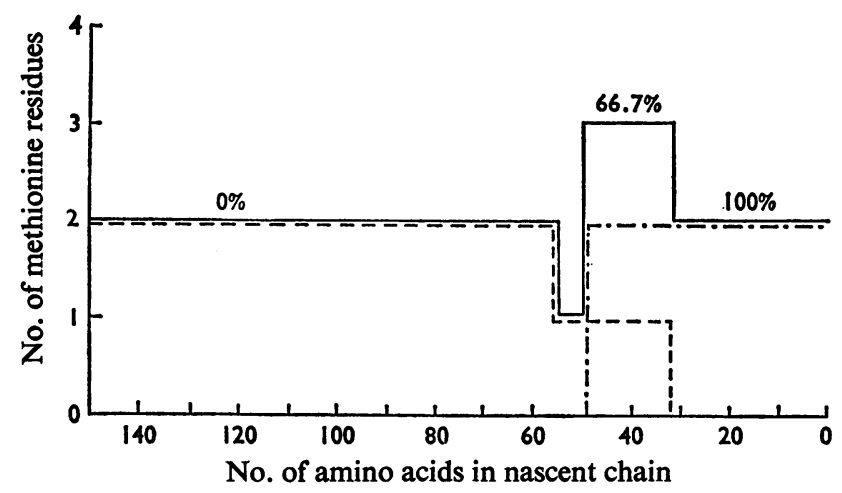

Fig. 7. Distribution of $N$-terminal and internal methionine residues in an equimolar mixture of globin $\alpha$ and $\beta$ chains

The diagram shows the presence of methionine in nascent globin peptides of increasing size. Percentages of $N$ terminal methionine are shown, calculated on the basis that the $N$-terminal residues are cleaved when the nascent chains are 50 amino acid residues in length. ----, Internal methionine; - - - - , $N$-terminal methionine; total methionine.

cytes from all but short nascent chains is also in agreement with earlier determinations of the amount of valine present as the $N$-terminal amino acid of nascent protein, which led to the conclusion that most if not all the incomplete globin chains have free valine at the amino terminal end (Mosteller et al., 1968; Rahamimoff \& Arnstein, 1969). Rahamimoff \& Arnstein (1969) noted, however, that the observed value for the $N$-terminal valine content of nascent globin $(12.3 \%)$ was lower than would be expected if all the nascent peptides contained this amino acid at the amino terminus $(14.6 \%)$ and the presence of $N$-terminal methionine on nascent globin chains shorter than 22 amino acid residues would account for this discrepancy between the experimental and calculated values. Rahamimoff \& Arnstein (1969) also observed that nascent chains synthesized in cell-free incubations contained less $N$-terminal valine than those obtained from intact cells, the experimental value $(8.1 \%)$ being compatible with cleavage of $N$-terminal methionine in vitro from nascent chains containing 65 amino acid residues. It seems possible therefore that cell-free incubation conditions are less efficient than intact cells at removing the $N$-terminal methionine residue of nascent protein.

Since ribosomes protect a length of nascent protein corresponding to some 30 amino acids against digestion by external proteolytic enzymes (Malkin \& Rich, 1967), Jackson \& Hunter (1970) suggested that methionine aminopeptidase may be a ribosomal protein. The results of our cell-free experiments indicate, however, that cleavage of the $\mathrm{N}$-terminal methionine of nascent globin chains can occur some time after the nascent protein has emerged from the ribo- some, and therefore the methionine aminopeptidase may be a cytoplasmic enzyme. Alternatively, the enzyme could be present on the surface of the ribosome but functions only when the nascent peptide has acquired a particular tertiary structure, for example a loop, which would bring the $N$-terminal methionine into contact with the ribosomal surface, and this reaction may be slower under conditions in vitro. The observation (Pemberton et al., 1972) that in the biosynthesis of duck globin $\alpha$ II chains by a rabbit reticulocyte lysate the $N$-terminal methionine is not removed suggests that the specificity of the cleavage reaction is related to the structure of nascent peptide chains as well as to their length.

The elution profiles of radioactive peptides from the Sephadex column indicate an accumulation of nascent peptides that are about 32-50 amino acid residues long, a peak being reached at a chain length of about 50 (Fig. 4a). In the presence of cycloheximide the peaks of radioactivity in this region were smaller, though still apparent (Fig. 4b). The distribution of radioactivity in peptides larger than 55 residues (effluent volume $225 \mathrm{ml}$ ), where the incorporation of the second internal methionine into the $\beta$ chain is indicated by an increase in ${ }^{3} \mathrm{H}$ radioactivity, is less meaningful because the fractionation of peptides of this size is no longer linearly dependent on the effluent volume. Moreover, some of the larger peptides may not be completely released from the ribosomes.

Various rate-limiting steps in the translation of globin messenger have been proposed (Naughton \& Dintzis, 1962; Englander \& Page, 1965; Itano, 1966; Winslow \& Ingram, 1966), but Hunt et al. (1968) 
demonstrated a uniform distribution of nascent globin peptides in intact rabbit reticulocytes and therefore concluded that normally protein synthesis proceeds at a uniform translation rate. Nevertheless abnormal conditions, e.g. tryptophan starvation, can clearly give rise to one or more rate-limiting steps (Hunt et al., 1968). If the lysates used in our experiments are by chance relatively deficient in the methionine aminopeptidase, our results could be interpreted on the basis that the consequent delay in the removal of the $N$-terminal methionine residue from nascent globin results in a decreased rate of elongation before position 50 is reached. The cycloheximide experiments would then be explained by the antibiotic slowing down the general translation rate and thus increasing the relative rate of removal of the $N$-terminal methionine.

The elution profiles (Figs. 3, 4 and 6) also show that a considerable amount of radioactivity corresponding to free amino acids, particularly methionine, is released by the treatment of ribosomes with alkali. Because precautions were taken to obtain uncontaminated ribosomal pellets by centrifugation through sucrose layers containing unlabelled amino acids, it is likely that this material originates from ribosomebound methionyl tRNA and other aminoacyl tRNA species. The significance of this observation is not clear at present.

\section{Initiation of protein synthesis in rat liver}

Although serum albumin accounts for approx. $30 \%$ of the total hepatic protein synthesis (Campbell, 1964), liver proteins are very heterogeneous. Thus a complex mixture of $N$-terminal amino acids was obtained by the dansylation method. In addition to glutamic acid, which is the $N$-terminal residue of rat serum albumin (Sargent \& Campbell, 1965), several neutral amino acids and aspartic acid appear to be present as $N$-terminal amino acids of cytoplasmic and ribosomal proteins. When nascent liver proteins were labelled with $\left[{ }^{14} \mathrm{C}\right]$ glutamic acid, either by protein synthesis in vivo or in a cell-free system, the amount of $N$-terminal glutamic acid estimated from the radioactivity of the dansyl derivative ranged from 0.3 to $1.0 \%$ (Table 3). Because of the heterogeneity of liver proteins the interpretation of these results is necessarily subject to uncertainties, but in view of the presence of 85 glutamic acid residues in internal positions of rat serum albumin the observed values are not inconsistent with the possibility that glutamic acid may be the $N$-terminal residue of a considerable proportion of nascent polypeptides in rat liver. In these experiments, some radioactivity was also associated with pyrrolidonecarboxylic acid, but this compound may be an artifact produced by cyclization of glutamic acid or glutamine.

In contrast to the comparatively small percentage of $N$-terminal glutamic acid, Edman degradation of perchloric acid-precipitable peptides (Table 5 and Fig. 6) showed that approx. $12 \%$ of the total methionine was present in the $N$-terminal position. As rat serum albumin contains only six internal methionine residues compared with 85 glutamic acid residues, and other liver proteins may also have different contents of these two amino acids, this relatively high proportion of $N$-terminal methionine may be partly accounted for by the differences in amino acid composition. However, because completed cytoplasmic liver proteins contain much less than half this amount $(3.3 \%)$ of $N$-terminal methionine, a more likely explanation of these results is that initiation of protein synthesis in liver, as in other eukaryotic cells, takes place by incorporation of methionyl tRNA. Removal of some of the $N$-terminal methionine residues then follows either during elongation of nascent chains or soon after release of the completed polypeptides. It is of interest in this connexion that results of recent experiments with HeLa cells, in which protein synthesis had been synchronized by previous exposure to fluoride, suggest that most of the nascent proteins synthesized in vivo by these cells are also initiated by methionine (Chatterjee et al., 1972). To obtain further information about the presence of $N$-terminal methionine, rats were injected with $\left[{ }^{3} \mathrm{H}\right]$ methionine, labelled nascent peptides were isolated from the liver ribosomes and fractionated by chromatography on Sephadex G-50 before being analysed by the Edman degradation. The presence of $N$-terminal methionine mainly on nascent chains shorter than approx. 65 amino acid residues and the observation that the percentage of $N$-terminal methionine decreases with increasing chain length indicate that the process of chain initiation in the biosynthesis of liver proteins is fundamentally similar to the mechanism that has been more fully established for globin synthesis by reticulocytes. One may speculate that in liver the presence of the endoplasmic reticulum protects some of the nascent chains against the action of methionine aminopeptidase, particularly if this enzyme is cytoplasmic.

We thank the Medical Research Council for a research grant and King's College for the award of a Tutorial Studentship to A. K.-G.

\section{References}

Arnstein, H. R. V., Cox, R. A. \& Hunt, J. A. (1964) Biochem. J. 92, 648-661

Bernfield, M. R. \& Nestor, L. (1968) Biochem. Biophys. Res. Commun. 33, 843-849

Blombäck, B. (1967) Methods Enzymol. 11, 398-411

Boyer, S. H., Hathaway, P., Pascasio, F., Bordley, J., Orton, C. \& Naughton, M. (1967) J. Biol. Chem. 242, 2211-2232 
Braunitzer, G., Best, J. S., Flamm, U. \& Schrank, B. (1968) Hoppe-Seyler's Z. Physiol. Chem. 347, 207-211

Bray, G. A. (1960) Anal. Biochem. 1, 279-285

Bresler, S., Grajevskaya, R., Kirilov, S., Saminski, E. \& Shutov, F. (1966) Biochim. Biophys. Acta 123, 534-545

Brown, J. L. (1971) Biochim. Biophys. Acta 221, 480-488

Caffier, H., Raskas, H. J., Parsons, J. T. \& Green, M. (1971) Nature (London) New Biol. 229, 239-241

Campbell, P. N. (1964) Progr. Biophys. Mol. Biol. 15, 338

Chatterjee, N. K., Kerwar, S. S. \& Weissbach, H. (1972) Proc. Nat. Acad. Sci. U.S. 69, 1375-1379

Englander, S. W. \& Page, L. A. (1965) Biochem. Biophys. Res. Commun. 19, 565-570

Gros, C. \& Labouesse, B. (1969) Eur. J. Biochem. 7, 463470

Hunt, T., Hunter, T. \& Munro, A. (1968) J. Mol. Biol. 36, $31-45$

Hunt, T., Hunter, T. \& Munro, A. (1969) J. Mol. Biol. 43, 123-133

Itano, H. (1966) J. Cell. Physiol. 67, Suppl. 3, 65-75

Jackson, R. \& Hunter, T. (1970) Nature (London) 227, 672-676

Koffer-Gutmann, A. (1972) Ph.D. Thesis, University of London

Konigsberg, W. (1967) Methods Enzymol. 11, 461-469

Lamfrom, H. \& Knopf, P. M. (1964) J. Mol. Biol. 9, 558575

Lengyel, P. \& Söll, D. (1969) Bacteriol. Rev. 33, 264-301

Lucas-Lenard, J. \& Lipmann, F. (1971) Annu. Rev. Biochem. 40, 409-448
Luppis, B., Bargellesi, A. \& Conconi, F. (1970) Biochemistry 9, 4175-4179

Malkin, L. I. \& Rich, A. (1967) J. Mol. Biol. 26, 329-346

Marcker, K. A. \& Smith, A. E. (1969) Bull. Soc. Chim. Biol. 51, 1453-1458

McKeehan, W. \& Hardesty, B. (1969) Biochem. Biophys. Res. Commun. 36, 625-630

Mosteller, R. D., Culp, W. J. \& Hardesty, B. (1968)J. Biol. Chem. 243, 6343-6352

Naughton, M. A. \& Dintzis, H. M. (1962) Proc. Nat. Acad. Sci. U.S. 48, 1822-1830

Pemberton, R. E., Housman, D., Lodish, H. F. \& Baglioni, C. (1972) Nature (London) New Biol. 235, 99-102

Ragnotti, G., Lawford, G. R. \& Campbell, P. N. (1969) Biochem. J. 112, 139-147

Rahamimoff, H. \& Arnstein, H. R. V. (1969) Biochem. J. 115, 113-124

Sargent, J. R. \& Campbell, P. N. (1965) Biochem. J. 96, 134-146

Smith, A. E. \& Marcker, K. A. (1970) Nature (London) 226, 607-610

Wettstein, F. O., Staehelin, T. \& Noll, H. (1963) Nature (London) 197, 430-435

Wigle, D. T. \& Dixon, G. H. (1970) Nature (London) 227, 676-680

Wilson, D. B. \& Dintzis, H. (1970) Proc. Nat. Acad. Sci. U.S. 66, 1282-1289

Winslow, R. M. \& Ingram, V. M. (1966)J. Biol. Chem. 241, 1144-1149

Yoshida, A., Watanabe, S. \& Morris, J. (1970) Proc. Nat. Acad. Sci. U.S. 67, 1600-1607 